\title{
Amadeus
} International Multidisciplinary Journal ISSN 2525-8281

V.3, N.6, 2019. p.09-13. - ISSN 2525-8281

\section{From Bentinho to Dom Casmurro: Pathological jealousy and psychic suffering in the work of Machado de Assis}

Pedro Walisson Gomes

Feitosa ${ }^{l}$

Maria Andrezza Gomes Maia ${ }^{l}$, Mariana Oliveira Aragão ${ }^{1}$,

Pedro Lourenzo Oliveira

Cunhal,

Heloísa Fernandes Caracas ${ }^{1}$, Fabio Gomes de Oliveira ${ }^{l}$,

Eulina Alves Sousa Brito Modesto Leite Rolim Neto ${ }^{3}$
Abstract: Dom Casmurro was published for the first time in 1899 by the writer Machado de Assis. This novel, since that time, causes doubts and uncertainties in his readers about the fidelity of the character Capitu and the veracity of the information narrated by Bentinho. Therefore, a brief description of the narrative of this enigmatic Brazilian book is necessary. We seek to analyze the descriptions about the psychic suffering of the character of Bentinho and his narrowing with the pathological jealousy. This article followed a method of documentary analysis, using, in addition to the masterpiece of Machado de Assis, bibliographic studies related to the research theme. Moreover, we include a brief history and theoretical foundation on psychic pain and pathological jealousy. We highlight as a latent difficulty, the reduced number of researches in this methodological line that could contribute to the inferences about the Machado de Assis's literary work.

Keywords: Dom Casmurro, Machado de Assis, Literature, Psychology

\footnotetext{
${ }^{\mathbf{1}}$ Medical Student at Federal University of Cariri - UFCA - Ceará, Brazil

Correspondent author: gomesfeitosa.walisson@outlook.com;

${ }^{2}$ Leão Sampaio University Center - Ceará, Brazil;

${ }^{3}$ Federal University of Cariri - UFCA - Ceará, Brazil;
} 


\section{Introduction}

Machado de Assis was a Brazilian writer of the nineteenth century that showed in his works a critical and accurate look over society, typical characteristic of Realism. In that sense, in 1899, he published the book Dom Casmurro, which has generated, since that time, doubts and uncertainties in his readers about the fidelity of the character Capitu and the veracity of the information narrated by Bentinho. Therefore, a brief description of the narrative of this enigmatic Brazilian book is necessary.

Don and Casmurro. With the irony between the meanings of these words, the character Bento Santiago initiates his story narrating how received this sobriquet. It wasn't just an average denomination; it became the reflection of what he became in the end of his life. Bentinho, as the character preferred, tries to tie the two life's tips, old age and childhood, throughout the book, but as him makes the point of approaching, couldn't recompose what was.

The promise of Bentinho's mother to make her son priest, after the loss of her eldest son, dealt with in the first chapters, seemed to end the friendship between him and Capitolina, the sweet Capitu. However, in the seminary, the beginning of a friendship with Ezequiel de Souza Escobar, the friend Escobar, brought a solution to the promise and love for Capitu. Leaving the seminary, Bentinho studies law, becomes a lawyer and marries his beloved. The story of happiness of the couple finds an obstacle in the delay in having a son that arrived after a few years, receiving the name of Ezequiel, in homage to the great friend of Bento. Escobar had married Sancha, Capitu's friend. The narrowing of the friendship between the couples promotes reflection and distrust on the part of Capitu's husband, who happens to see in the son, resemblance to the best friend.

In: (Assis, 1971) "If it was not the astronomy, i wouldn't discover so soon the ten pounds of Capitu; but it is not for this that I return to her, is so that you do not take care that the vanity of a teacher is what made me suffer with Capitu's inattention and be jealous of the sea. No, my friend. I come to explain to you that I had such jealousies for what it could be on my wife's head, not outside or above her." Between jealousy, love and uncertainty, Bento Santiago tells the story of his marriage, his life, which ends with tragedy and loneliness. 
Therefore, it tries to analyze the descriptions about the psychic suffering of the character of Bentinho and his narrowing with the pathological jealousy. This article followed a method of documentary analysis, using, in addition to the masterpiece of Machado de Assis, bibliographic studies related to the research theme. We also consider pertinent a brief history and theoretical foundation on psychic pain and pathological jealousy.

\section{About the psychic suffering jealousy pathological jealousy}

According to Freud, the failure of devices to protect sums of large amounts of neuronal excitation, both endogenous and exogenous, reverberates in the representation of psychic pain. Once the pain occurred, it is represented by affection, a pulsional representing, intermediating the access of the pulsion to the psychic sphere. (Caropreso \& Monzani, 2012).

In this way, the feelings express the awareness of the variations of intensity of the unconscious tensions. There is, however, a basic difference between displeasure and pain: since displeasure is a high tension of the drives that can be modulated, the pain is an extreme and uncontrollable tension that causes deregulation of the pulsional cadence. Love leaves the individual unprotected against suffering, since when there is the loss of the loved person or his love, the unhappiness is irremediable (Freud, 2006). What triggers the affect of psychic pain or pain of loving is the pain of mourning, when there is a brutal rupture with the beloved; pain of abandonment, when the beloved suddenly withdraws his love; of humiliation, when self-esteem is wounded; and pain of mutilation, when there is loss of part of the body. The more you love, the more you suffer (Nasio, 1997).

The psychic pain is the affect that express in consciousness the perception of rupture of a tie with the beloved and this affect unchains in consciousness the defensive reaction against the commotion meanwhile the I fight to find himself (Nasio, 1997). Consonant Cavalcante (1997) about the pathological jealousy: “... a total disturbs, a grave affective disorder. The jealous suffers in his love: in his confidence, in his tranquility, in his self-love, in his spirit of domination, and in his spirit of possession. Jealousy erodes the feeling at its base and destroys, with angry rage, its own roots. It leads to the invasion of the doubt that disturbs the soul, causing it to love and hate at the same time, the person object of his affection. 
The biggest suffering of the jealous is the uncertainty in which he lives, by the impossibility of knowing, with insecurity, if the partner deceives him or not. In this bias, the psychic disturbance of Bentinho, in front of his love for Capitu, suggests signs of a pathological event, represented by sick jealousy.

The love and admiration described by the narrator before his deceased wife represent a tenuous threshold between hatred and contempt. Undaunted by Dom Casmurro's wishes for Capitu, the narrative presents what would surely be the current danger between loving and hating by giving himself hopelessly to another being that becomes his own existence, Bentinho reveals in situations where his love would be a justification for acts that disregard ethics and respect. In this way, pathological jealousy represents, besides the person affected by this psychological disorder, a social risk to the other people who live with it.

As stated in Nasio (1997): "Unlike the body pain caused by an injury, the psychic pain occurs without aggression to the tissues. The reason that triggers it is not in the flesh, but in the tie between the lover and his beloved object. When the cause is in this protection envelope of the self that is the body, we qualify the body pain; when the cause lays morebeyond the body, in the immaterial space of a powerful bond of love, pain is called psychic. "Therefore, surely Bentinho, already named "Dom Casmurro" suffers from the pain of losing Capitu and consequently, his dreams of desires in life. In addition, the "Dom Casmurro" would have faced a "pathological mourning". A process of pain caused by the rupture of death. Meanwhile, the death of Capitu's naive love, led to exaggerated attachment and paradoxical care, in which, in order to have Capitu closer to him, he sometimes considers it to hurt her.

\section{Final considerations}

It is noted that Bentinho silences the character of Capitu from the first to the last page, leaving the reader in a position of passivity in front of his story. Soon, the signs of betrayal described with contempt by Bentinho cannot be considered, since they are all drawings of his mind that at times showed signs of psychic disturbance. The narrator, represented by attitudes of jealousy, exaggerates in all the described occasions. Bentinho, already Casmurro, aims to understand the events that took place between his life and that of Capitu. As Marchezan (2008) states: "The narrator of Dom Casmurro, after 40 years, 
recalls his life and seeks his conscience; tries to identify certain events with certain behaviors, in order to delimit, rather, the bulge of that question, its individuality and, hence, to establish a concept of himself. Bento Santiago questions his identity. The identity thinking is wide".

Thus, the adult Bento, suffering, conscious of his suffering, eroded by jealousy, identified with the pain, questions the Bentinho with no identity, created between three widows and an asexual. Between the boy and the man, a suburban story, and a plot, this, through the observations of a confessed Casmurro.

\section{References}

Caropreso, F., \& Monzani, L.R. (2012). Vivência de dor e pulsão de morte na teoria freudiana do aparelho psíquico e das neuroses. Revista Mal-Estar e Subjetividade, XII (34), 607 - 638. Available at: http://pepsic.bvsalud.org/pdf/malestar/v12n3-4/05.pdf.

Freud, S. S. (2006). O futuro de uma ilusão, o mal-estar na civilização e outros trabalhos (1927-1931) (Vol. 21). Rio de Janeiro, Rio de Janeiro, Brasil: Imago.

Nasio, J. D. (1997). O livro da dor e do amor. (2 ed.). Rio de Janeiro, Rio de Janeiro, Brasil: Zahar.

Assis, M. de. (1971). Dom Casmurro. Editora Abril, 230.

Cavalcante, A. M. (1997). O ciúme patológico. Record: Rosa dos tempos, 300.

Marchezan, L. G. (2008). As Metáforas da Casa e do Mar em Dom Casmurro. Revista da anpoll, 1 (24).

\section{How to cite this article (APA format):}

Feitosa, P. W. G.; Maia, M. A. G.; Aragão, M. O.; Cunha, P. L. O.; Caracas, H. F.; Oliveira, F. G. de; Britto, E. A. S.; Rolim Neto, M. L. (2019). From Bentinho to Dom Casmurro: Pathological jealousy and psychic suffering in the work of Machado de Assis. Am. In. Mult. J., April. (6) 3, 0813.

Received: 03/28/2019

Accepted: 04/19/2019 